\title{
An Excerpt from “Living \& Loving Better with Time Perspective Therapy: Healing from the Past, Embracing the Present, Creating an Ideal Future"
}

\author{
Philip Zimbardo* and Rosemary Sword \\ Stanford University, USA \\ *Corresponding author: Philip Zimbardo, Ph.D., Professor Emeritus, Stanford University, USA
}

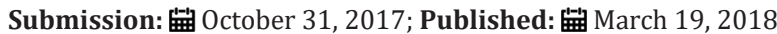

\section{How Time Perspective Can Cause Toxic Relationships - and What To Do}

Warning: The following may be upsetting - especially for those who may have been, or are currently in, a toxic relationship.

"You are a fat pig! You look like a cow! The house is a pigsty! You are so lazy!"

Jennifer sat head in hands, fearful and anxious, as she willed herself to be invisible. After a year of living with her boyfriend Lee, she had slowly grown accustomed to his rants. But this time was different. She shook uncontrollably as he shouted a litany of her perceived failings. Somehow, the strong, confident, independent girl that had attracted Lee in the beginning of their relationship had been replaced by a scared, cowering, shadow of the person she used to be. She worried that the agitated state she endured each time Lee rampaged - the anxiety and panic attacks she experienced on a now daily basis followed by bouts of depression - would cause permanent damage to her psyche - or cause her to suffer a heart attack or stroke.

"Well? What do you have to say for yourself?" Lee spat at her.

Jennifer raised her head and took stock of Lee: She noted the crazed look in his eyes, the bulging veins in his neck, the foam forming at the corners of his mouth, like a mad beast.

"You left out bitch," she said quietly. Her response further enraged Lee. He yelled "You bitch!" Enraged to the point of physical violence, Lee seized a handful of books and threw them at her. A part of her mind detached from the brutal scene she was enduring to think ahead wondering how she would explain the bruises to her co-workers. What excuses should she start planning? As Jennifer stood to leave, Lee gripped her wrist and seethed, "Where do you think you're going?" The rage that contorted his face rendered him unrecognizable. Just as she had been replaced by a victim, the man she thought she loved had changed into a cruel bully. She muttered she had to use the bathroom immediately or she would have an accident where they stood. Lee released her and followed her down the hall.

Jennifer shut and locked the bathroom door. She spent the next half hour sitting on the toilet, listening to Lee alternate between throwing things around and banging on the bathroom door, demanding she come out. She knew that soon he would get tired and leave the house. After he hoarsely yelled that he was going out to get drunk, she tentatively opened the door, called her sister, packed a bag and walked into the alley where her sister picked her up minutes later.

Jennifer had reached rock bottom. She wanted to stop the pattern of toxic relationships in her life. She wanted what she thought a relationship with Lee would bring her just some simple happiness. Her sister, who had been a client of our clinical psychology office, told her of the new way she had learned of looking at time through the Time Perspective Therapy (TPT) we had developed and how it had helped her overcome her PTSD following a car accident. She suggested us to Jennifer for counseling. In therapy, Jennifer explained that she was the youngest of three sisters, all of whom had been raised in an abusive household. Her parents argued constantly, her father would occasionally become physically violent toward her mother and, as his daughters grew into womanhood, he hit them as well. Jennifer's sisters moved out of the house as soon as they could, leaving Jennifer to fend for herself.

Jennifer was thirteen when she had her first boyfriend. He was seventeen. Having an older boyfriend made Jennifer feel special and powerful; after all, she - not her girlfriends - had attracted an older boy. Surely this meant that she was more mature and desirable than her gal pals. And maybe he would protect her from her father's rages. But in a matter of weeks, her boyfriend became verbally abusive. Jennifer accepted as normal name calling and being accused of things she didn't do. It wasn't until a girlfriend mentioned her boyfriend was fooling around behind her back with multiple girls - that Jennifer took exception to his behavior. When she confronted him, he broke up with her, saying he didn't have to put up with her whining because there were plenty of girls interested in him.

This toxic relationship was the first in a long series of poisonous affairs Jennifer found herself in; the last being with boyfriend Lee. But after we reviewed these experiences with her, Jennifer saw that actually the original toxic relationship she experienced was that between her parents, and that as far as romantic relationships were 
concerned, it was all she ever knew. Being stuck in the mire of her past negative experiences, Jennifer recreated the only relationships she identified with - over and over again. Toxic relationships had caused her to live a life of chronic stress, anxiety and depression. She imagined that her destiny was to forever be sad and unloved. However, in a relatively brief period through experiencing Time Perspective Therapy, she learned how to replace the negatives in her life with positives, to turn around 180 degrees to face the future instead of the past, create a brighter, more positive future for herself, and enjoy the goodness in herself in the present.

Sometimes you can see a toxic relationship heading your way like a bullet train but at other times it creeps up on you so slowly that you are unaware you are in one until it's nearly impossible to exit. Most of us have experienced - or are currently in - one or more toxic relationships. We question how they can be avoided and maybe even consider if we are the toxic person. We may also ponder why, after experiencing past negative toxic relationships before, we continue to draw them into our lives, or why we are continually vulnerable to the negative lure by Mr. or Ms. Toxic Agent.

\section{The Many Faces of Toxic Relationships}

Toxic relationships can occur in every aspect of our lives and in every type of relationship, from acquaintances to significant others and from co-workers and landlords. You know the type - you lend a family member money, or a co-worker your car, or you care for their children while they go on vacation hoping they will one day return the favor. Unfortunately, the toxic person never pays you back, returns your car damaged with no offer to repair it, and even has the guts to ask you to watch their children again next vacation without ever offering to watch yours. It doesn't happen once, it happens repeatedly in different forms. You feel hurt, taken advantage of and angry - at the offender - and worse, about yourself. The bottom line is: You are constantly being brought down. You feel "used" and sometimes even abused.

\section{Past Negative Time Perspective and the Toxic Relationship}

The unconscious need to seek out toxic relationships - a behavior that may last a lifetime - more than likely commenced during childhood with past negative experiences. They can become so deeply ingrained in the way we think and feel that we don't realize we are steeped in toxicity until-or hopefully when - someone else points it out. The toxic person in our lives - and maybe it's us - is generally concerned about themselves and their needs - meaning they may be narcissist - and the relationship is classic co-dependent. One of the most harmful forms of toxic relationships is that of significant others, partners in life for better and unfortunately, for worse.

\section{Five Signs You're in a Toxic Relationship}

In our research, we discovered it's possible to distill the myriad indicators of toxic relationships into the following five signs:

\section{Nothing you do is right}

They mock everything you do, including your personality, and you feel ashamed most of the time. Since you are constantly being put down, condemned and judged, you adopt characteristics you think will please the toxic person, at least when you are around her/him.

\section{Everything is about them and never about you}

You have feelings too, but the other person won't hear them. Two-way conversations are non-existent as your opinion is inconsequential. Instead of acknowledging your feelings, they battle with you until they get the last word.

\section{You realize you don't enjoy yourself when you are together}

Trials abound on a daily basis and frequently you are the reason for the stream of complaints. Their attempt to control your behavior is an attempt to control your happiness.

\section{You're uncomfortable being yourself around that person}

You don't feel free to speak your mind. You have to put on a different face just to be accepted by that person. You realize you don't even recognize yourself anymore and worse yet, you may not even like the person you've become in this relationship.

\section{Your evolution is unconscionable}

When your intent is self- improvement, you are ridiculed. There is no encouragement or support for your efforts. Instead, they keep you stuck in old judgments and ineffective habits by insisting that you will never be any different than you are now.

If you're experiencing even just one of these signs, check in with yourself to see if the relationship is doing more damage than good. And then consider a remedial action plan.

\section{What happened to Jennifer?}

Through Time Perspective Therapy, Jennifer eventually came to realize that, while she initially found her boyfriend to be emotionally and intellectually stimulating, he was incapable of and disinterested in making any effort to build a healthy, loving, supportive long-term relationship. Rather than walk away, they both sunk into a toxic downward spiral. She hung in there trying to make it work, and he became increasingly angry and abusive. Both had already been divorced, and were determined not to "fail" again.

While her boyfriend took no personal responsibility, Jennifer was unconsciously willing to endure whatever punishment he meted out in order to avoid another such painful and defeating loss. Although he initially agreed to attend couples counseling, which Jennifer arranged and paid for, other than the first session in which the boyfriend asked the couple's counselor to "Fix her," Jennifer was the only one to show up for months. During this time her boyfriend demonstrated his lack of care and commitment, maintaining there was no reason for him to participate as she was the one to blame for all their problems.

Jennifer took the opportunity to explore the question: Why had she been drawn into such a toxic relationship? She discovered that to a large degree, she was caught in the past negative experience of growing up in her parents' toxic relationship household. She 
recalled to the counselor how her parents, despite years of leading separate lives, had stayed together "for the sake of the children"; their unhappiness devolving into complete disconnection while living under the same roof. Jennifer realized that merely staying together did not constitute a successful relationship or partnership. And, while trying to save her relationship, she had - like her mother before her -lost her true authentic self as she futility strove to be whom and what she thought her boyfriend wanted her to be.

After making every possible effort to salvage her relationship, Jennifer accepted that there was no hope for a future positive with her boyfriend. She was finally ready to let go and move on. With healthy introspection, a few more counseling sessions, and some encouragement from loved ones, Jennifer found herself and her self-respect once again. With this new mindset, she able to focus on personal growth and living a meaningful, toxic-free life. She learned to recall happy, past positive memories from her childhood to replace the past negatives of growing up in a toxic household whenever they popped up, practiced selected present hedonism by taking time to do things she enjoyed doing, and looked forward to a brighter future. Eventually Jennifer did find love, happiness, satisfaction and fulfillment - within herself and a successful marriage.

Excerpt from "Living and Loving Better with Time Perspective Therapy: Healing from the Past, Embracing the Present, Creating an Ideal Future," by Philip Zimbardo and Rosemary Sword. McFarland, 2017. This book will be published in Polish language by PWN and Hungarian by Libri Kiado in 2018. Other time perspective books: The Time Cure, Wiley 2012 and The Time Paradox, 2008.

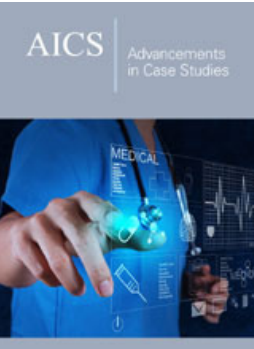

\section{Advancements in Case Studies}

Benefits of Publishing with us

- High-level peer review and editorial services

- Freely accessible online immediately upon publication

- Authors retain the copyright to their work

- Licensing it under a Creative Commons license

- Visibility through different online platforms 